\title{
Play and Learning?
}

\section{A Critical Discourse Analysis of the Treatment of Play in Relation to Learning in Australian and New Zealand Early Childhood Curricula Frameworks}

\author{
Fiona WESTBROOK | ORCID : 0000-0002-0744-6721 \\ RMIT University, Melbourne, Australia \\ fiona.westbrook@rmit.edu.au
}

Elise HUNKIN | ORCID : 0000-0001-6390-8233

RMIT University, Melbourne, Australia

elise.hunkin@rmit.edu.au

\begin{abstract}
The role of play in early childhood settings has become a global issue due to coordinated policy trends that privilege early learning, academic foci and formalised assessments amid a broader economic and investment agenda. This paper undertakes a critical discourse analysis of the Australian and New Zealand national early childhood curricula frameworks in order to examine the treatment of play and learning as they relate to one another. The analysis revealed that curriculum documents from both Australia and New Zealand drew on lifelong learning ideological frames to present a view of play as an activator of learning, where learning is interpreted as observable and recognisable academic processes. It was found that the agency attributed to the child in play and learning processes was central to how the role of the adult was interpreted, with implications for the play opportunities that children may encounter.
\end{abstract}

\section{Keywords}

play - learning - early childhood curriculum - policy - critical discourse analysis

\section{$1 \quad$ Introduction}

Play as "a basis for learning" is a widely theorised and recognised view within early childhood literature (Brook et al., 2014, p.2), however the relationship 
between play and learning has a long history of contestation, often positioned across "dialectic poles" (Samulesson \& Pramling, 2014, p. 169) or conflated as one process or experience. This contestation has been reinvigorated in recent times, with educational and early childhood reform globally focused on the systematisation and standardisation of early childhood classrooms through prescriptive and 'schoolified' (Bradbury, 2019; Grieshaber \& Ryan, 2018) interpretations of learning, such as, via outcomes, standardised assessments and so on (Brown et al., 2012). The concern is that within this schoolification and "datafication of early childhood pedagogy" (Roberts-Holmes, 2014, p. 302) the role and importance of play has been increasingly minimised (Wasmuth \& Nitecki, 2017; Sims, 2017), or perhaps, reinterpreted by technocratic "risk-adverse" and "accountability-driven" policy regimes (Brown et al., 2012, p. 10). Multiple theories have been put forward as to why play is undervalued, such as safety fears, commercial media (Alcock, 2013; Lewis, 2017), push down curriculums and an emphasis on capitalist values (Barblett, et al., 2016; Wood, 2014). Building on these discussions, this paper applies Fairclough's (1992) framework for critical discourse analysis (CDA) to the early childhood curricula frameworks of Australia and New Zealand to investigate how the curricula frameworks conceptualise and represent the relationship between play and learning, and the social and political thought that orient language use (Fairclough, 1992).

\subsection{Economic Agenda and Competitive Discourses in Education and Early Childhood Policy}

Globally, education systems have become valuable commodities since being recast as essential to a competitive knowledge economy (Fairclough 2006; OECD 2006). As Davies and Bansel (2007) emphasise, this is a neoliberal view of education as a service for human capital formation and of education as a private, human capital. Manifest in public policy, the neoliberal cornerstones have been the distancing of the nation state from public services, and the related priorities of self-determination and individualism, competition and choice (Carney, 2009). The view of the individual as responsible for his or her own 'self-capitalising' relies on free markets, and so promotes individual interests over the collective and common good (Lingard, 2010, p. 141). Hence, market- or neo-liberalism promotes a competitive ethic by acknowledging others only as they affect the individual's progress - other as consumers, competitors or markets (Yeatman, 2017), leading to a broader culture of competition or, survival of the fittest.

Since education is seen as a broker for each citizen (and nations) future economic success (Mundy et al., 2016), global public policy trends have emerged that draw on 'packages' (Ball 2003) of managerialism, privatisation 
and accountability. These policies systematise, standardise and nationalise education fields to allow for competition in an international field of comparison (Lingard 2010), as well as to steer market inputs and outputs and with them, the way that the market behaves and operates (Adamson \& Brennan, 2014). Common examples include learning and teaching standards and/or outcomes, best practice packages or frameworks, teacher and student standardised accountability systems, often with inbuilt reward (or punishment) facets that encourage competition and compliance (Apple, 2005; Westbrook, 2018). These re-imaginings and reforms have encompassed early childhood policy which has become increasingly systematised and standardised amid a broader global shift toward developing services in ways that serve the economy (Grieshaber \& Ryan, 2018). Policies that emphasise competition and comparison through standardisation have their origins in the United States and United Kingdom but have "had considerable international influence" in shaping early childhood systems in the global north and global south (Grieshaber \& Ryan, 2018, p. 261; also see Sims 2017), typically around notions of quality (Hunkin, 2019). Early childhood curricula frameworks are one such policy, designed to affect the inputs and outputs of early childhood services.

In Australia, the development and introduction of Belonging, Being and Becoming: The Early Years Learning Framework for Australia (EYLF) (Department of Education, Employment and Workplace Relations [DEEWR], 2009) took place as part of broader suite of reforms called the National Quality Framework, that sat within the national workforce productivity and participation agenda (COAG 2009). This was a human capital investment agenda for public services that included early childhood sector investment, a welcome change after the long period of policy neglect that followed the marketisation of services in 1991 (Hunkin, 2016). The Commonwealth drew on human capital messages of cost and benefit to re-imagine early childhood services as the first step in a cycle of lifelong learning that is essential for a competitive global economy (Gillard, 2008). As the first Australian national curriculum framework for early childhood, the EYLF (DEEWR, 2009) sits alongside state and territory curricula frameworks and must guide educational programming for centres to meet accreditation and regulation requirements (ACECQA, 2012).

In 2017, New Zealand's national curriculum Te Whāriki (Ministry of Education[MoE], 2017) underwent its first update since its introduction in 1996. The first version of Te Whäriki (MoE, 2017) was highly acclaimed as a holistic, bi-cultural document that drew on socio-cultural theoretical approaches (OECD, 2004; Mara, 1998; May, 2009; Moss et al., 2016). Farquhar emphasised its cultural promise, stating "the Māori [indigenous New Zealander] child, seen as a social misfit in the colonialist settler tradition, now had a legitimate identity 
within Aotearoa New Zealand" (2015, p. 60). The recent update has caused some tension within the sector, due in part to the perceived input from a rightwing National Government (Westbrook, 2018). Concerns have been raised about a re-write that emphasises the "institutionalisation of children" and "reduction of children's rights to quality education and the best of care" (Alexander, 2016, p. 25; Early Childhood Council, 2017), as well as the concern that $T e$ Whäriki (MoE, 2017) had been infiltrated by an economic agenda and the competitive discourse (Westbrook, 2018). This agenda comes amid a broader bipartisan investment approach (May, 2009; Nuttal, 2018) that has led to increasing concerns about the "irreconcilable differences" of Māori ways of being and knowing in comparison to economic, Westernised ideologies such as neoliberalism (Rata, 2008, p. 37).

\subsection{Investment Discourse and Schoolification}

State investment in early childhood services has increased in recent times in tandem with a view of the early years as a sensitive period of development and learning that can influence education outcomes in the short and long term (Moss, 2014). This is a lifelong learning agenda that reinterprets early childhood settings as preparation for schooling services and frames 'schoolified', academic interpretations of the desired human capital outputs of early childhood programs (SIms, 2017; Urban, 2015). Smith, Tesar and Myers describes this as an 'edu-capitalism' agenda that dominates both Australian and New Zealand early childhood policy (2016, p.128). This has resulted in policy reform trends that seek to formalise and systematise early childhood content (Farquhar, 2008; Westbrook, 2018) in order to privilege academic interpretations of learning such as pre-determined skills and knowledge as measured by explicit criteria or outcomes (Neaum, 2016).

The 'schoolification' of early childhood settings has gone hand in hand with attempts to 'professionalise' the early childhood workforce through education agenda and discourse (Osgood, 2009) that seek to make learning and 'teaching' more visible (Duhn, 2010; Wood; 2014; Woodrow \& Press, 2007). Managerial and business interpretations of the educator as a "technicist" (Wood, 2014, p. 151) proliferate policy, hence, policies promoting the professionalisation of the early childhood workforce often draw on performativity and accountability mechanisms to enforce control and technical competence (Osgood, 2009).

\subsection{The Place of Play}

Play is a complex and contested notion, with its role and contribution to early learning and development the subject of broad discussion across different contexts. Yet, as Grieshaber and Ryan (2018) point out, when children's learning 
is reconceptualised as an economic investment in future human capital, present moment learning opportunities through play are devalued and eroded (also see Sims, 2017; Wasmuth \& Nicketi, 2017). Further, play opportunities that do occur are reinterpreted as spaces for teaching academic skills. In fact, as play pedagogy is the foundation of Western world approaches to early childhood education, "at the heart of 'schoolification' (or readiness) discourse is the place of play" (Grieshaber \& Ryan, 2018, p. 266).

Early childhood curricula have been noted as key to the shifting role of play in early childhood settings in Anglophone countries even when countries mandate a play-based approach, due to the reinterpretation of the role of play (Grieshaber \& Ryan, 2018). Woods (2014) notes that early childhood curriculum in England emphasises adult interaction and structured play, which raises concerns about the type of play opportunities children encounter. Play does not fit well into formalised attributes or interpretations of learning due to its abstract and fluid nature and "multiplicity of meanings" (Lewis, 2017, p. 11). This leads Wood to conclude that when play is altered by adults seeking "effective pedagogic interactions....it is likely that the complex benefits of play will be lost" (2014, p. 147). The adaption of play-based curricula has also been observed in Canada, where teacher's struggle to "balance between academic curricular expectations and play-based pedagogy" (Fesseha \& Pyle, 2016, p. 375). Key to the shifting role of play in the United States, that is not governed by a national curriculum, is government intervention, including the aftermath of No Child Left Behind that distanced play-based learning, focusing on accountability discourses, proficiency and academic foci (Johnson, 2014; McGuinn, 2016).

In the Australian context, Ortlipp, Arthur and Woodrow (2011) note that the EYLF (DEEWR, 2009) promotes neoliberal education discourse through a view of early childhood education as 'learning,' 'teaching' and 'educating', rather than the historically dominant mix of education, care and development. Similarly, the revised Te Whäriki (MoE, 2017) has been noted as focused on assessment and intentional teaching, leading to concerns about a shift away from "facilitating child led play towards didactic teaching" (Giardiello et al., 2019, p. 163). These power dynamics emerge because lifelong learning agenda encourage a shift away from notions of 'learning through play' toward an emphasis on learning activities that prepare for future education (Jackobi, 2012). This leads Alexander (2016) to raise concerns that government are using early childhood curricula to narrow settings and pedagogy in ways that meet government agenda. We add to these existing discussions by employing Fairclouch's (1992) framework for critical discourse analysis (CDA) to the Australian and New Zealand early childhood curricula in order to interrogate how the texts shape ways of thinking about the relationship between play and learning, and therefore practices. 
This paper applies Fairclough's framework for critical discourse analysis (CDA) which conceives of discourse as text, discursive practice and social practice (1992, p. 62). Discourse, therefore, is "language use as a form of social practice" (Fairclough, 1992, p. 64) inclusive of constructed orders and conventions that define specific spaces and institutions, and ideologies (Fairclough, 2001). Within these orders and conventions are the "power in" and "power behind discourse" (Fairclough, 2001, p. 46). Both forms of power naturalise taken for granted ideas and actions over time "controlling and constraining the contribution of nonpowerful participants", as well as leading to dominant ideologies that influence social knowledge, beliefs and practices (Fairclough, 2001, p. 46). This makes CDA particularly productive for policy analysis because it allows us to consider specific discursive events within the socio-political context that generated them, since "political contexts are institutional contexts" (Fairclough, 2012, p. 18). Political texts are written to persuade, to provide reasoning that incite actions that meet the ideology and agenda of the institution (Fairclough, 2012).

Fairclough reflects that "critical discourse analysis can in fact draw upon a wide range of approaches to analysing text" (2003, p. 6), depending on the purpose of the analysis. To analyse the ways that discourses of play and learning were presented in Australian and New Zealand early childhood curricula in relation to one another, we have employed Fairclough's (1992) critical discourse analysis tools of metaphor and transitivity. Metaphor reflects a single word within a text that emphasises a particular way of seeing or thinking about a subject (Fairclough, 1992). Transitivity refers to the "grammatical aspects of the clauses or sentences that relate to its ideational meaning" (Fairclough, 1992, p. 27) and focuses the analysis on the how discourse is signified in process. This is an analysis of the subject and object positioning or put simply, who/what acts and how. Only sentences and paragraphs in which both play and learning were analysed, due to scope.

\section{$3 \quad$ Findings}

\subsection{Metaphor}

Metaphor usage in political texts presents a way of seeing or thinking about a subject, with the view to shape related actions toward that future (Fairclough, 2012). In both curricula, metaphor was employed to frame ways of thinking about early childhood curricula- what they are and do. New Zealand early childhood curriculum framework Te Whāriki (MoE, 2017) states that: 
A curriculum whäriki for young children provides a rich array of primarily play-based experiences. By engaging in these, children learn to make sense of their immediate and wider worlds through exploration, communication and representation. Young children are developing an interest in literacy, mathematics and other domain knowledge. They can exhibit highly imaginative thinking. (p. 15, Emphasis added)

The "whäriki", tereo(Māorilanguage) metaphor is a woven mat, enlisted above as a way of thinking about bicultural curriculum as a supporting force for all to gather upon, and the basis for all early childhood experiences. Situating a 'rich array of play-based experiences' within the woven mat metaphor presents a view of play as intricate, repeated elements or experiences in abundance. An array, likea woven mat, is a predictable pattern of repeating elements, and so the view of play as knowable and observable is presented as common sense through the metaphor. Although play-based experiences are described as constitutive of a whäriki curriculum, the experiences are not valued out of hand but rather, because by engaging in these, childrenlearn'. This is a play andlearning relationship in which theformer isvalued in its service to the latter. Similarlogics can be observed in the deployment of metaphor in Australia's EYLF (CoA, 2009), as follows:

The Framework forms the foundation for ensuring that children in all early childhood education and care settings experience quality teaching and learning. It has a specific emphasis on play-based learning and recognises the importance of communication and language (including early literacy and numeracy) and social and emotional development. The Framework has been designed for use by early childhood educators working in partnership with families, children's first and most influential educators. (p. 5 , emphasis added)

In the above excerpt, the metaphor of a foundation presents the view of curriculum as the starting point or underlying basis for quality experiences in early childhood settings, creating an authority for the text and presenting that authority as taken-for-granted. A foundation is strong and solid, a material, touchable and therefore knowable entity. Whilst 'play-based learning' is acknowledged as central to the foundation it is presented as an animator and marker of 'quality teaching and learning' and broader and more robust understandings of the play and learning processes are not sought. The examples given of the types of learning that children explore through play reflect dominant education discourse and agenda, as indicated by references to academic subjects and domains. 
These choices of metaphor are more than "rhetorical flourish" (Fairclough, 1992, p. 208), both seek to discursively structure the relationship between play and learning within certain academic opportunities, practices and outcomes.

\subsection{Transitivity}

A transitivity analysis is concerned with the use of grammar to indicate who or what acts and how, in a given sentence or clause (Fairclough, 1992). Analysis of the EYLF (CoA, 2009) and Te Whäriki (MoE, 2017) sentence and/or clause treatments of play and learning reflected the dominant view that children's learning was activated by play, as follows (emphasis added):

- Te Whariki: Children learn through play: by doing, asking questions, interacting with others, devising theories about how things work and then trying them out and by making purposeful use of resources. As they engage in exploration, they begin to develop attitudes and expectations that will continue to influence their learning throughout life. (MoE, 2017, p. 46)

- EYLF: Play-based learning: a context for learning through which children organise and make sense of their social worlds, as they engage actively with people, objects and representations (CoA, 2009, p. 6)

- EYLF: Play provides opportunities for children to learn as they discover, create, improvise and imagine. When children play with other children they create social groups, test out ideas, challenge each other's thinking and build new understandings. (CoA, 2009, p. 17)

The transitivity analysis reveals a consistent view of play as a powerful and important because it is the subject that acts on the goal (learning) (Fairclough, 1992). Both curricula provide elaborations to describe play activating learning, and do this by describing processes that are observable, active and easily recognisable as processes of academic learning, such as questioning, thinking, building and testing hypothesis. The emphasis on play and learning as visible, knowable processes links to the choice of metaphor discussed above, and strongly indicates a lifelong learning ideological frame embeds the interpretations of play and learning processes. This contributes to our understanding of why Australian educators report feeling as though time for play-based learning is dwindling (Barblett et al. 2016), as well as broader pressure to teach phonics (Campbell, 2015) which often stems from parental demands (Ewing, 2018). Similarly, New Zealand teachers have also raised concerns that "free-play" within early childhood is being " "taken over" by economic forces" under a "broader agenda, specifically within neoliberal approaches to education” (Stover, 2016, p. 539).

There is a tension present between the power and importance attributed to play by the curricula frameworks, and the limited ways that play is presented and understood in regard to learning. Both the EYLF (CoA, 2009) and Te Whäriki 
(original 1996 version) were written in broad consultation with early childhood sector academics, professionals and advocates but Leach-McGill (2018) notes that the early childhood sector will adopt a neoliberal discourse to seize powerfully policy opportunities, progressing early childhood centric values through the language of investmentand progress (also see Hunkin, 2016). The CDA quotations above raise questions about how effectively lifelong learning and education discourse can interpret and reflect the depth and breadth of play and learning, since learning through playhasan "elusive and ambiguousnature" (Sutton-Smith, 2001, p. 3). This ambiguous and seemingly "whimsical" quality means that some processes of learning are less recognizable (Lewis, 2017, p. 10), measurable and observable (Penn, 2011), particularly within academic interpretations of learning.

This tension is particularly apparent when the ideational frame is applied to interpret the role of the adult in play and learning in the EYLF (CoA, 2009), as follows (emphasis added):

- Educators draw on a rich repertoire of pedagogical practices to promote children's learning by: adopting holistic approaches; being responsive to children; planning and implementing learning through play; intentional teaching; creating physical and social learning environments that have a positive impact on children's learning $\square$ valuing the cultural and social contexts of children and their families providing for continuity in experiences and enabling children to have successful transition assessing and monitoring children's learning to inform provision and to support children in achieving learning outcomes. (2009, p. 16)

- Responsive learning relationships are strengthened as educators and children learn together and share decisions, respect and trust. Responsiveness enables educators to respectfully enter children's play and ongoing projects, stimulate their thinking and enrich their learning. (2009, p. 17)

- Educators are also responsive to children's ideas and play, which form an important basis for curriculum decision-making. In response to children's evolving ideas and interests, educators assess, anticipate and extend children's learning via open ended questioning, providing feedback, challenging their thinking and guiding their learning. They make use of spontaneous 'teachable moments' to scaffold children's learning. (2009, p. 17)

- Early childhood educators take on many roles in play with children and use a range of strategies to support learning. They engage in sustained shared conversations with children to extend their thinking. They provide a balance between child led, child initiated and educator supported learning. They create learning environments that encourage children to explore, solve problems, create and construct. (2009, p. 17). 
The above practice examples show the pedagogical implications of the 'play as an activator of learning' view, insofar as 'quality' pedagogical practices are interpreted as the adult intercepting play for academic purposes such as instruction and assessment.

This is a professionalisation agenda as interpreted by lifelong long and education discourse, and communicates an assumption that academic learning would not occur to the same extent without such interference, which is contestable. In fact as Wood (2014) points out, adult interference in play to progress these types of academic goals and agenda can stifle the rich and complex processes of play, limiting its potentials.

Te Whäriki (MoE, 2017) presents a more passive view of the adult role in play and learning, as follows:

- To learn and develop to their potential, children must be respected and valued. This means recognising their rights to have their wellbeing promoted and be protected from harm and to experience equitable opportunities for participation and learning and for rest and play (2017, p. 18)

- [children's] play is valued as meaningful learning and the importance of spontaneous play is recognised (2017, p. 25 \& p. 47).

- Do all children experience fair and equitable access to, and participation in, play and learning opportunities? (2017, point 2, p. 40)

- How effectively is the ece setting organised to maximise the play, learning and participation of all children? (2017, point 2, p. 40)

- An understanding that trying things out, exploring, playing with ideas and materials and collaborating with others are important and valued ways of learning. (2017, p. 47)

Above, the notion that play activates learning has been interpreted as a less active mandate for adults, with the pedagogical practices outlined above focused on creating and sustaining the conditions in which children can play and learn. This is significant because it suggests that it is not necessarily the perceived relationship between play and learning that drives academic and technocratic constructions of teaching and learning, but the perceived role of the human subjects in these processes and, in particular, the perceived role of the child. Faircough (1992) emphasises that transitivity clauses can provide insight into the degree of agency the theoretical frame ascribes to human subjects. What we can observe from the EYLF (CoA, 2009) and Te Whäriki (MoE, 2017) transitivity clauses is that the variation in the agency attributed to the child in activating (academic) learning through play in turn affects the interpretation of the role of the adult - with implications for the play opportunities that children may encounter. 
The CDA undertaken in this paper provides a starting point for discussion, having applied two of Fairclough's (1992) CDA tools to show that both the New Zealand and Australian early childhood curricula promote the view of play as an activator of learning. As lifelong learning ideology frames this interpretation, more robust notions and processes of play were not explored in relation to learning, creating tensions between the espoused value and power of play and the narrow, academic interpretations of learning presented in the curricula. Further analysis indicated how important notions of agency are in mitigating these forces, particularly the agency of the child. In Te Whäriki (MoE, 2017) children were assumed more agency in play and learning processes than in the EYLF (CoA, 2009) so the role of the adult was interpreted as less invasive and technocratic. This points to educator pedagogy around child agency as playing an important role in mitigating or exacerbating the pressures created by curricula that privilege academic interpretations of learning.

These findings highlight the importance of sustaining broad, robust conversations about play and learning and children within the early childhood sector. Policies are persuasive and designed to further certain agenda and ideology but policies are not pedagogy, nor are they presentations of 'truth'- no matter the metaphors employed to suggest this. Future research directions could usefully include children's competence and agency in play and learning processes, broadly conceived, particularly as can be explored via methodologies that incorporate supported opportunities for education activism and change-making.

\section{References}

Adamson, E., \& Brennan, M. (2014). Social Investment or Private Profit? Diverging Notions of 'Investment' in Early Childhood Education and Care. International Journal of Early Childhood, 46(1), 47-61.

Australian Children's Education and Care Quality Authority [ACECQA]. (2012). National Quality Standards. Australian Children's Education and Care Quality and Authority. http://www.acecqa.gov.au/national-quality-framework/the-national-qualitystandard.

Alcock, S. (2013). Searching for Play in Early Childhood Care and Education policy. New Zealand Journal of Educational Studies; Heidelberg, 48(1), 19-33.

Alexander, S. (2016). Questions Hanging over the Update of Te Whäriki. Child Forum. https://www.childforum.com/. 
Apple, M. W. (2005). Education, Markets, and an Audit Culture. Critical Quarterly, 47(12), 11-29. https://doi.org/10.1111/j.0011-1562.2005.00611.x.

Ball, S. J. (2003). The Teacher's Soul and the Terrors of Performativity. Journal of Education Policy, 18(2), 215-228.

Barblett, L., Knaus, M., \& Barratt-Pugh, C. (2016). The Pushes and Pulls of Pedagogy in the Early Years: Competing knowledges and the erosion of play-based learning. Australasian Journal of Early Childhood, 4r(4), 36-43.

Bradbury, A. (2019). Datafied at Four: the role of data in the 'schoolification' of early childhood education in England. Learning, Media and Technology, 44(1), 7-21.

Brennan. (1998). The Politics of Australia Child Care: philanthropy to feminism and beyond. Cambridge University Press.

Brennan, D. (2014). The Business of Care: Australia's Experiment with the Marketisation of Childcare. In C. Miller \& L. Orchard (Eds.), Australian public policy: Progressive ideas in the neoliberal ascendency (pp. 151-167). Public Policy.

Brooke, E., Blaise, M., \& Edwards, S. (2014). Introduction. In E. Brook, M. Blaise, \& S. Edwards (Eds.), The sage Handbook of Play and Learning in Early Childhood (pp. 14). Thousand Oaks, Sage Publications.

Brown, F., Patte, M., \& Jones, P. (2012). Rethinking Children's Play. Bloomsbury Publishing.

Campbell, S. (2015). Feeling the Pressure: Early childhood educators' reported views about learnign and teaching phonics in Australian prior-to-school settings. Australasian Journal of Language and Literacy, 38(1), 12-26.

Carney, S. (2009). Negotiating Policy in an Age of Globalisation: Exploring Educational "Policyscapes" in Denmark, Nepal, and China. Comparative Education Review, 53(1), $63-88$.

Davies, B., \& Bansel, P. (2007). Neoliberalism and Education. International Journal of Qualitative Studies in Education, 20(3), 247-259. https://doi.org/10.1080/09518 390701281751 .

Department of Education, Employment and Workplace Relations. (2009). Belonging, being and becoming: The early years learning framework for Australia. https://www .acecqa.gov.au/sites/default/files/2018-02/belonging_being_and_becoming_the_ early_years_learning_framework_for_australia.pdf.

Duhn, I. (2010). 'The Centre is My Business': Neo-Liberal Politics, Privatisation and Discourses of Professionalism in New Zealand. Contemporary Issues in Early Childhood, 11(1), 49-6o. https://doi.org/10.2304/ciec.2010.11.1.49.

COAG. (2009). National Partnership Agreement on the National Quality Agenda for Early Childhood Education and Care. https://cabinet.qld.gov.au/documents/20og/Nov/ National\%2oQuality\%2oAgenda\%2ofor\%2oEarly\%2oChildhood\%2oEd\%2o and\%2oCare/Attachments/national_partnership_on_early_childhood_education .pdf. 
Early Childhood Council. (2017). Council Welcomes New Curriculum - with One Big Reservation. http://www.scoop.co.nz.

Ewing, R. (2018). Exploding some of the Myths about Learning to Read: A review of research on the role of phonics. Nsw Teachers Federation.

Fairclough, N. (1992). Discourse and Social Change. Polity Press.

Fairclough, N. (2001). Language and Power (2nd ed). Longman.

Fairclough, N. (2003). Analysing Discourse: Textual Analysis for Social Research. Taylor \& Francis [CAM].

Farquhar, S. (2008). Early Childhood Care and Education: From advocacy to institution. In V. Carpenter (Ed.), Nga kaupapa here: Connections and contradictions in education (pp. 46-56). Cengage Learning.

Farquhar, S. (2015). New Zealand Early Childhood Curriculum: The politics of collaboration. Journal of Pedagogy, 6(2), 57-70. https://doi.org/10.1515/jped-2015-0013.

Fesseha, E., \& Pyle, A. (2016). Conceptualising Play-based Learning from Kindergarten teachers' PerspectivesInternational Journal of Early Years Education, 24(3), 361-371. https://doi.org/10.1080/og669760.2016.1174105.

Giardiello, p., Geraldine, L., \& Hargreaves, A. (2019). Te Whāriki. In N. McLeod \& P. Giardiello (Eds.), Empowering Early Childhood Educators: International pedagogies as provocation (pp. 157-174). Routledge.

Gillard, J. (2008). Budget 2008-2009: Education Revolution. http://www.budget.gov .au/2008-o9/content/ministerial_statements/download/Education.pdf.

Grieshaber, S., \& Ryan, S. (2018). The Place of Learning in the Systematization and Standardization of Early Childhood Education. In G. E. Hall, L. F. Quinn, \& D. M. Gollnick (Eds.), The Wiley Handbook of Teaching and Learning (1st edition, pp. 257277). John Wiley \& Sons.

Hunkin, E. (2016). Deploying Foucauldian Genealogy: Critiquing 'quality' reform in early childhood policy in Australia. Power and Education, 8(1), 35-53. https://doi .org/10.1177/1757743815624114.

Hunkin, E. (2018). Whose Quality? The (mis)uses of Quality Reform in Early Childhood and Education Policy. Journal of Education Policy, 33(4), 443-456. https://doi.org/10 $.1080 / 02680939.2017 .135^{2032}$.

Hunkin, E. (2019). Being Seen and Being Changed: a story of 'quality' Early Childhood Education and the Global Education Reform Movement. In M. Gasper \& L. Gibbs (Eds.), Thinking About Pedagogy in Early Education Series: Policy Intersecting Pedagogy. (Vol. 6, pp. 193-209). Routledge.

Johnson, J., E. (2014). Play Provisions and Pedagogy in Curricular Approaches. In E. Brooker, M. Blaise, \& S. Edwards (Eds.), The sage Handbook of Play and Learning in Early Childhood (pp. 180-191). Sage Publications.

Leach-McGill, D. (2018). The Impact of Policy on Early Childhood Education and Care Professionals Working in Integrated Service Settings. (Doctoral dissertation, The University of Melbourne, Melbourne, Australia). http://hdl.handle.net/11343/214752. 
Lewis, P. J. (2017). The Erosion of Play. International Journal of Play, 6(1), 10-23. https:// doi.org/10.1080/21594937.2017.1288391.

Lingard, B. (2010). Policy Borrowing, Policy Learning: Testing times in Australian schooling. Critical Studies in Education, 51(2), 129-147.

Mara, D. (1998). Implementation of Te Whäriki in Pacific Island Centers. Final Report to the Ministry of Education. New Zealand Council for Educational Research.

May, H. (2009). Politics in the Playground: The world of early childhood in New Zealand (Rev. ed., [2nd ed.]). Otago University Press.

McGuinn, P. (2016). From No Child Left behind to the Every Student Succeeds Act: Federalism and the Education Legacy of the Obama Administration. Publius: The Journal of Federalism, 46(3), 392-415. https://doi.org/10.1093/publius/pjwo14.

Mellor, E. (1990). Stepping Stones: The development of early childhood services in Australia. Harcourt Brace Jovanovich.

Ministry of Education. (2017). Te whāriki: He whāriki mātauranga mō ngā mokopuna o Aotearoa: Early childhood curriculum. Wellington Learning Media.

Moss, P. (2014). Transformative Change and Real Utopias in Early Childhood Education: A story of democracy, experimentation and potentiality. Routledge.

Moss, P., Dahlberg, G., Grieshaber, S., Mantovani, S., May, H., Pence, A., Rayna, S., Swadener, B. B., \& Vandenbroeck, M. (2016). The Organisation for Economic Co-Operation and Development's International Early Learning Study: Opening for debate and contestation. Contemporary Issues in Early Childhood, 17(3), 343-351. https://doi .org/10.1177/1463949116661126.

Mundy, K., Green, A., Lingard, B., \& Verger, A. (2016). Handbook of Global Education Policy. Wiley Blackwell.

Neaum, S. (2016). School Readiness and Pedagogies of Competence and Performance: Theorising the troubled relationship between early years and early years policy, International Journal of Early Years Education, 24(3), 239-253. https://doi.org/10.108o/ og669760.2016.1205970.

Nuttall, J. (2018). Engaging with Ambivalence: The Neglect of Early Childhood Teacher Education in Initial Teacher Education Reform in Australia. In C. Wyatt-Smith \& L. Adie (Eds.), Innovation and Accountability in Teacher Education: Setting Directions for New Cultures in Teacher Education (pp. 155-169). https://doi.org/10.1007/ 978-981-13-2026-2_10.

OECD. (2004). Starting Strong: Curricula and pedagogies in early childhood education and care-five curriculum outlines. OECD.

OECD. (2006). Starting Strong ii: Early Childhood Education and Care. OECD.

OECD. (2019). The International Early Learning and Child Well-being Study - The study. http://www.oecd.org/.

Ortlipp, M., Arthur, L., \& Woodrow, C. (2011). Discourses of the Early Years Learning Framework: constructing the early childhood professional. Contemporary Issues in Early Childhood, 12(1), 56-70. 
Osgood, J. (2006). Deconstructing Professionalism in Early Childhood Education: Resisting the Regulatory Gaze. Contemporary Issues in Early Childhood, 7(1), 5-14. https://doi.org/10.2304/ciec.2006.7.1.5.

Rata, E. (2008). The Politics of Educational Equality. In V. Carpenter, J. Jesson, P. Roberts, \& M. Stephenson (Eds.), Ngā kaupapa here: Connections and contradictions in education (pp. 36-46). Cengage.

Learning. Roberts-Holmes, G. (2014). The 'Datafication' of Early Years Pedagogy: 'if the teaching is good, the data should be good and if there's bad teaching, there is bad data'. Journal of Education Policy, 30(3), 302-315.

Samulesson, I. P., \& Pramling, N. (2014). Children's Play and Learning and Developmental Pedagogy. In E. Brooker, M. Blaise \& S. Edwards (Eds.), The Sage Handbook of Play and Learning in Early Childhood (pp. 169-179). Sage Publications.

Sims, M. (2017). Neoliberalism and Early Childhood. Cogent Education; Abingdon, 4(1). http://doi.org/10.1080/2331186X.2017.1365411.

Smith, K., Tesar, M., \& Myers, C. Y. (2016). Edu-capitalism and the Governing of Early Childhood Education and Care in Australia, New Zealand and the United States. Global Studies of Childhood, 6(1), 123-135. https://doi.org/10.1177/2043610615625165.

Stover, S. (2016). The Educationalising of Early Childhood in Aotearoa New Zealand: Tracking "free play" 1940s-2010. Paedagogica Historica, 52(5), 525-541. https://doi.or g/10.1080/00309230.2016.1170709.

Sutton-Smith, B. (2001). The Ambiguity of Play. Harvard University Press.

Urban, M. (2015). From 'Closing the Gap' to an Ethics of Affirmation: Reconceptualising the Role of Early Childhood Services in Times of Uncertainty. European Journal of Education, 5o(4). http://doi.org/10.111/ejed.12131.

Wasmuth, H., \& Nitecki, E. (2017). Global Early Childhood Policies: The impact of the global education reform movement and possibilities for reconceptualization. Global Education Review, 4(2), 1-17.

Westbrook, F. (2018). Shifting Tectonic Plates of Key Discourses in New Zealand Early Childhood Education Policy (1989-2017): A critical discourse analysis at the dawn of change (Masters thesis, The University of Waikato). https://hdl.handle.net/10289/ 12079.

Wood, E. (2014). The Play-Pedagogy Interface in Contemporary Debates. In E. Brooker, M. Blaise \& S. Edwards (Eds.), The Sage Handbook of Play and Learning in Early Childhood (pp. 145-156). Sage Publications.

Woodrow, C., \& Press, F. (2007). (Re)Positioning the Child in the Policy/Politics of Early Childhood. Educational Philosophy and Theory, 39(3), 312-325. https://doi.org/ 10.1111/j.1469-5812.2007.00328.x.

Yeatman, A. (2017). The Question for Our Times: Institution Design for a Free Society. Whitlam Institute: Western Sydney University. https:/www.whitlam.org/ publications $/ 2017 / 10 / 4 /$ the-question-for-our-times-institutional-design-for-a-freesociety. 